\title{
PITTA, Eduardo. Persona. Braga, Portugal: Ângelus Novus, 2000.
}

Edgard Pereira

Universidade Federal de Minas Gerais

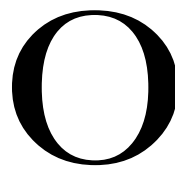

título Persona originase do latim, referindo a antiga máscara dos atores. Ao articular-se à categoria personalidade, indicia o caráter do indivíduo que se afirma como pessoa dotada de reservas morais. Uma nota não assinada, pese seu significado de letra, edição e marginália, tenta esclarecer circunstâncias de tempo e espaço relacionadas ao contexto: "Persona é uma trilogia de contos morais, com ação localizada em Moçambique e na África do Sul, nos anos sessenta e setenta. (...) Qualquer semelhança com fatos e pessoas é mera coincidência". A existência desse aviso instaura uma estratégia escamoteadora do pacto autobiográfico, aparentemente neutralizado pelo foco narrativo em terceira pessoa e pelo próprio estatuto ficcional. O volume engloba três relatos "Marilyn", "Kalahari" e "Pesadelo", este de maior desenvolvimento e espessura, em toda acepção. Apesar da autonomia, podem ser lidos como movimentos decisivos no processo de formação da mesma personagem, atuando em circunstâncias distintas. Chama-se Afonso, um nome emblemático para a cultura portuguesa. Alguma insistência na moralidade das ações, para além de possíveis efeitos teatrais, é sintomática do contrapeso repressor de que se revestem os aparelhos institucionais e de Estado, na iminência da ruína e do esfacelamento. Quando o império português começa a declinar em África, solapado por séculos de arbitrariedade, exclusão social e racial, rapina e exploração, o que deve ser ocultado é muito menos o colapso do poder do que a sexualidade desviante e exacerbada da/ na colônia. Híbrido, múltiplo, sensual, o espaço africano surge como campo de forças onde reverberam os experimentos pseudo-científicos, os ícones da cultura pop, as referências à cultura gay e as manipulações da pulsão erótica. O mais paradoxal, entretanto, é que os atores mais eficientes no 
exercício da violência e da repressão (a disciplinarização dos corpos, a vigilância punitiva) pertencem à raça branca, postos na mais alta hierarquia.

A trilogia de contos de Eduardo Pitta mistura a evocação da guerra colonial em Moçambique, distanciada do natural enquadramento político, à liberação do corpo e da sexualidade, num contexto-limite de trocas culturais e reciprocidade. A mãe do protagonista, hesitante entre a perplexidade e o zelo burguês, diante da arbitrária prisão do filho que se prolonga além do previsto, desaba: "O que é que ele tinha a ver com questões de vulnerabilidade e segurança do Estado?" (p. 27) A contigüidade da libertação política e da concepção libertária da sexualidade é percebida pelos aparelhos estatais (entendase imperiais) como o desmoronar de um domínio que se imaginava consistente e eterno. Disso terá certeza o narrador onisciente, ao encerrar o livro: "Decididamente o mundo começava a ruir". (p. 54) O último conto atinge em cheio as estruturas supostamente sólidas do império luso, ao revelar criticamente o lado pouco convencional de um quartel, desvelando a sexualidade nada exemplar de diversos e notáveis atores sociais (administradores, oficiais, capelães, recrutas, etc.). Os outros lugares focados na trilogia - a escola e o deserto - não são menos significativos no diagnóstico de uma literatura caudatária das preocupações (a)moralizantes da escrita libertina do século XVIII.

Nascido em Moçambique (Lourenço Marques, 1949) e radicado em Lisboa desde fins de 1974, Eduardo Pitta vem construindo uma obra em três vertentes: na poesia, no ensaio e, mais tardiamente, na ficção. Forjada na contenção e na síntese, a poesia dada a lume em África (Sílaba a sílaba,1974) contém as inquietações preliminares em torno da questão colonial, ainda presentes na coletânea seguinte (Um câo de angústia progride,1979). A seguir, sua poesia centrou-se na busca de compreender o sujeito em demanda da sexualidade, em especial em dois livros lançados na década de 80, Olhos calcinados (1984) e Archote Glaciar (1988). Colabora como ensaísta nas revistas Lere Colóquioletras, em particular interessado na produção literária contemporânea. Assinalável o seu trabalho pioneiro no âmbito dos gay studies em Portugal, com a publicação de Fractura-a condição homossexual na literatura portuguesa contemporânea (2003). Surpreende esta sua estréia, pela desenvoltura como constrói numa linguagem ágil, dinâmica, num português globa- 
lizado, receptivo a expressões mostrando-se capaz de inventar inglesas, francesas e crioulas, uma fatos não vividos, ou de contar os ficção alegre e ousada, refinada e vividos como se inventados fossem, demolidora, irônica e encharcada de ceticismo. Ninguém percebe sem temer o lado vulgar da realidade, a marca da lama ou do lodo, que antes atravessou o aparentemente plácido jardim da poesia. sem intimismo pegajoso, sem o tom de vítima por apalpar a lama ou o Depôs no limiar do exercício da lodo, quando necessário. prosa a rústica tesoura de podar, 